\title{
GÊNERO MONOGRAFIA EM CONTEXTO DE PRODUÇÃO ACADÊMICA ESCRITA'
}

\section{MONOGRAPH GENDER IN ACADEMIC WRITING CONTEXT}

\author{
Clara Regina Rodrigues de Souza² \\ Williany Miranda da Silva ${ }^{3}$
}

\begin{abstract}
RESUMO: O gênero monografia é uma açăo social que organiza a cultura acadêmica em fase de conclusăo de um curso universitário de Graduaçăo e Especializaçăo, bem como é uma açâo textual esquematizada na produçâo escrita. Para o presente artigo, tomamos seis exemplares deste gênero, oriundos de um curso de Letras e de Ciências Sociais, para, através de um estudo de casos múltiplos, com uma metodologia descritivointerpretativista, analisar o referido gênero e seus movimentos recorrentes na sua seçáo de introduçăo. Com o respaldo em abordagens sociorretóricas, de Swales (1990; 2004) e de Bhatia (2004; 2009), investigamos monografias no contínuo com outros gêneros de iniciaçáo no meio científico. Concluímos que elas revelam uma prototipicidade marcada por movimentos mais gerais, como identificaçăo de tema, apresentaçâo de objeto, questâo e objetivos de pesquisa. Além disso, por movimentos mais específicos, como, no caso dos nossos dados, a informaçăo de que as pesquisas săo derivadas de projetos desenvolvidos no programa institucional de fomento à formaçáo de pesquisadores (PIBIC), adaptandose ao contexto situacional e comunicativo que evoca.
\end{abstract}

PALAVRAS-CHAVE: Monografia; gêneros acadêmicos; escrita.

ABSTRACT: The monograph genre is a social action which organizes the academic culture at the conclusion stage of a Graduation and a Specialization university course, as well as it is a textual action laid out in written production. For this article, we select six copies of this genre, from Letters and Social Sciences courses, through a multiple case study, with a descriptive-interpretativist methodology, to analyze this genre and its recurring movements in your introduction section. Supported by sociorhetorical approaches, as Swales (1990; 2004) and Bhatia (2004; 2009), we investigate monographs in continuous with other initiation genres in the scientific domain. We

Este trabalho aprofunda questionamentos decorrentes da dissertaçâo Retextualizaçâo em monografias, defendida em 2014, pelo Programa de Pós-Graduaçâo em Linguagem em Ensino, da Universidade Federal de Campina Grande, na Paraíba. A pesquisa dissertada integrou o projeto investigativo As estratégias textuais e discursivas nos gêneros orais e escritos: da sala de aula ao ambiente virtual, coordenado pela

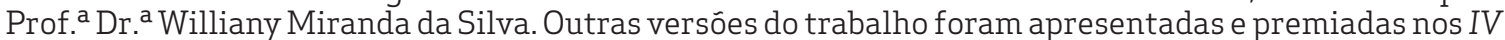
e V Gêneros na Linguística e na Literatura, respectivamente em 2013 e 2014, na Universidade Federal de Pernambuco (UFPE).

2 Doutoranda em Linguística pelo Programa de Pós-Graduaçăo em Letras, da UFPE, e professora substituta do Departamento de Letras e Artes, da Universidade Estadual da Paraíba. Desenvolve pesquisas, na área da Linguística do Texto e do Discurso e da Linguística Aplicada, que contemplam a produçăo de gêneros e retextualizaçâo na escrita acadêmica.E-mail: clararegina.r.s@gmail.com.

3 Professora Dra. da Pós-Graduaçáo em Linguagem e Ensino, da Universidade Federal de Campina Grande, e membro do grupo de pesquisa Teorias da Linguagem e do Ensino. Contato: williany.miranda@gmail.com 
conclude that they reveal a prototypicality marked by more general movements, as identifying theme, object presentation, question and research objectives. In addition, for more specific movements, in the case of our data, such as the information searches are derived from projects developed in the institutional promotion programme for the training of researchers (PIBIC), adapting to the situational context and communicative that evokes.

KEYWORDS: Monograph; academic genres; writing.

\section{CONSIDERAÇÕES INICIAIS}

A produçấo de monografias, por vezes, causa temor a um sujeito antes mesmo de ingressar em cursos de graduaçấo, por ecoar o mito de que é uma escrita para alguns poucos privilegiados a construir um trabalho de cunho científico. Essa repercussăo se torna mais contundente em espaço acadêmico, em que alunos sofrem diante dessas cristalizaçōes que supóem existir. Na tentativa de explicar para os leigos, para os que nâo têm familiaridade com práticas acadêmicas, o que é uma monografia, as definiçōes sâo diversas e angustiantes, além de reforçar a ideia arraigada: "é um trabalho que se faz para comprovar que se pode concluir o curso", "é como se fosse um livro que se escreve a duras penas".

A visăo mitológica é atestada em manuais de metodologia científica que se apresentam como desmistificadores dessa produçăo de momento conclusivo de graduaçáo, proliferando a crença de que escrever na academia é se adequar a uma linguagem objetiva, com regras estabelecidas. No entanto, mesmo se utilizando das regras, a falta de autonomia na escrita do gênero evidencia a insuficiência em seu domínio, já que costuma ser motivo de angústia e pavor depressâo para graduandos.

Diante dessa realidade, objetivamos situar o processo de escrita de monografias enquanto uma açâo social e textual; mais especificamente, analisar o referido gênero e seus movimentos recorrentes na sua seçăo de introduçăo. Este trabalho resulta da dissertaçâo de Mestrado que defendemos em 2014, por um programa de pós-graduaçăo em Linguística Aplicada (doravante LA), e como parte de um projeto de pesquisa que desenvolvemos desde 2010, acerca do tratamento dado às estratégias textuais de gêneros orais e escritos em ensino e aprendizagem. Aqui, aprofundamos nossos estudos sobre propósitos comunicativos em monografias, enfocando a açăo de introduzir uma pesquisa neste gênero. O trabalho se justifica por ampliar os debates sobre os gêneros acadêmicos, partindo da consideraçáo de que estas produçôes de fase conclusiva de graduaçâo mobilizam outras apreendidas em práticas de ensino/ aprendizagem. A consequente mobilizaçăo indica que um enfoque investigativo voltado para este gênero em particular possibilita compreender a cientificidade esperada em seu meio, por ser estabelecido pela (des)construçấo de conhecimentos validados, em um contínuo de apropriaçấo, reflexăo e contestaçâo de saberes produzidos.

Pesquisas vêm sendo realizadas sobre tais gêneros, notoriamente, depois da abordagem metódica de Swales (1990) sobre a escrita para fins acadêmicos. No Brasil, Motta-Roth (2001) se preocupa com resumos, resenhas, projetos de pesquisa e artigos acadêmicos, revistos em Motta-Roth e Hendges (2010). A partir de 2004, inicia-se a 
coleçăo de quatro volumes, Leitura e produçâo de textos técnicos e acadêmicos, sob a coordenaçấo de Anna Rachel Machado, com o objetivo de ser um material didático sobre gêneros acadêmicos. Dentre outros estudos, Bezerra (2001) contribui com análises de resenhas; também abordadas, juntamente com o resumo, em Matencio (2002; 2003; 2004); bem como E. M. Silva (2012) e Ferreira (2015) mostram resultados do ensino e da aprendizagem desses gêneros na universidade, evidenciando o desenvolvimento da competência comunicativa acadêmica.

No entanto, apesar de as últimas duas décadas revelarem o crescente interesse sobre o estudo de gêneros acadêmicos, há ainda um espaço promissor de investigaçăo a ser explorado. Em revisăo sistemática, Ferreira (2014) detecta que esse campo linguístico é pouco contemplado, através de um recorte que faz dos anos 2000 a 2013, nos Periódicos da Capes e no SciELO, vinculado à FAPESP, ao BIREME e ao CNPq. Em segunda revisăo, a autora seleciona seis revistas4 de Qualis A1, representativas da LA, de 1993 a 2013, e constata que apenas nove trabalhos diziam respeito à escrita na academia.

Além destas revisóes, um incurso ao nosso próprio Programa de Pós-graduaçăo em Linguagem e Ensino, que tem a LA como abordagem constitutiva, também evidencia as pesquisas na subárea em questăo como minorias dentre as demais dos estudos linguísticos. No programa, criado em 2004 , constatamos ${ }^{5}$ que somente quatro ${ }^{6}$ dissertaçóes investigaram produçáo escrita acadêmica, das 121 (cento e vinte e uma) defendidas entre 2006 e o primeiro período de 2014.

O breve estado da arte apresentado reflete a importância da realizaçáo de mais estudos sobre escrita acadêmica, constituída por gêneros textuais que têm poder institucional de oficializar conhecimentos. Discussōes acerca dessa escrita situada importam por esta ser objeto de estudo e aprendizagem para alunos, de ensino para professores e de produçâo, divulgaçấo e/ou investigaçâo para pesquisadores. De um lado, concordamos com Bazerman (2015), estudantes demonstram sua capacidade de aprendizagem e inteligência em situaçóes diversas para atender a determinadas exigências institucionais e docentes, mediante a produçăo de respostas a questóes e tarefas. De outro lado, professores (re)orientam e avaliam a aprendizagem de seus alunos pela escrita, além de conduzir sua própria prática docente. Ainda em outro posicionamento, pesquisadores desenvolvem suas pesquisas na produçâo escrita, porque na medida em que escrevem, refletem sobre seus experimentos, suas descobertas, seus questionamentos e resultados.

Em face das consideraçóes apresentadas, este artigo segue um plano organizacional em quatro tópicos, afora as consideraçóes iniciais e finais. No primeiro, situamos nosso contexto de pesquisa e o caráter de LA seguido. No segundo, apresentamos o

\footnotetext{
$4 \quad$ As revistas pesquisadas por Ferreira (2014) foram: Revista Brasileira de Linguística Aplicada - RBLA; Revista da Associaçáo Brasileira de Linguística - ABRALIN; Revista da Associaçáo Nacional de PósGraduaçāo e Pesquisa em Letras e Linguística - ANPOLL; Revista de Documentaçáo de Estudos em Linguística Teórica e Aplicada - DELTA; Revista de Estudos da Linguagem; e Trabalhos em Linguística Aplicada - TLA.

5 A constataçăo foi possível por meio do endereço: http://www.ual.ufcg.edu.br/posle/index.php/ Disserta\%C3\%A7\%C3\%B5es. Acesso em: 29 jul. 2014.

6 Săo elas: Morais (2006), Santos (2009), Andrade (2014) e Ferreira (2014).
} 
embasamento teórico de abordagem sociorretórica que nos fundamenta. No terceiro, apontamos a linguagem científica mobilizada na escrita de monografias e tratamos de defini-la, segundo o aval de estudos da sociorretórica e dos dados coletados. No quarto, seguimos com a descriçăo do gênero, enfocando sua açăo textual em propósitos comunicativos e movimentos retóricos.

\section{SITUANDO A PESQUISA DE LINGUÍSTICA APLICADA}

Considerando estudiosos como Cavalcanti (2004), Cavalcanti e Moita Lopes (1991), Kleiman e Cavalcanti (2007) e Moita Lopes (1996; 2006), nossa investigaçăo se posiciona nos estudos de LA, a partir de um problema situado de linguagem: a prática de escrita em contexto universitário. Além disso, porque tem a análise de gêneros textuais como um de seus interesses, da mesma maneira que trabalhos desses estudos também têm. Ao entendermos que a LA investiga questōes de linguagens em conjunturas sociais múltiplas, compreendemos o referido contexto como problemático e problematizado em nosso artigo. Nesse sentido, as escolhas teórico-metodológicas que fazemos decorrem da situaçăo de escrita ora contextualizada.

Desenvolvemos uma pesquisa do tipo documental, com base em Cellard (2008), a partir de documentos públicos, possíveis de serem disponibilizados à extensăo do contexto social de que fazem parte. Adotamos metodologia de natureza qualitativa, na relaçăo entre dados e teorias discutidas, conforme Strauss e Corbin (2008), bem como de cunho descritivo-interpretativista na análise de seis monografias, produzidas por sujeitos advindos do Programa Institucional de Bolsas de Iniciaçăo Científica (PIBIC), em cursos, do Centro de Humanidades, de uma Universidade Federal brasileira, que obtiveram conceituaçâo satisfatória no Exame Nacional de Desempenho de Estudantes (Enade): I) o de Bacharelado em Ciências Sociais, com conceito máximo 5; e II) o de Licenciatura Plena em Letras em Língua Portuguesa, com conceito 4. No caso das monografias de Letras, interessaram as da Área da Linguística, por pertencerem ao contexto da presente pesquisa.

Estas monografias foram recolhidas por meio de quatro critérios para geraçăo de dados. O primeiro critério é a seleção de monografias de sujeitos egressos do PIBIC, devido à responsabilidade do Programa ${ }^{7}$ de iniciar graduandos em práticas acadêmico-científicas, em projetos de pesquisas que desenvolvam métodos científicos e qualifiquem quadros para programas de pós-graduaçăo e para a formaçăo profissional, através de parceria entre Instituiçăo de Ensino Superior (IES), orientador e bolsista. $O$ segundo critério deriva deste primeiro, ao contemplar as monografias que tivessem sido orientadas por professores distintos, de modo que coletamos até um exemplar de cada orientador, assim, os dados representam grupos de pesquisas também diferentes entre si.

O terceiro é a seleçâo de monografias de cursos, do Centro de Humanidades, da universidade em investigaçăo, avaliados como satisfatórios pelo Enade. O encontro deste critério ocorre pela necessidade de delimitar o corpus de análise, sem perder de vista

Conforme disponível no portal do Conselho Nacional de Desenvolvimento Científico e Tecnológico (CNPq): http://www.cnpq.br/web/guest/pibic. Acesso em: 17 jun. 2013. 
a credibilidade de monografias pertencentes a um contexto privilegiado de produçăo: no caso do PIBIC, pelo suporte institucional de pesquisa científica; no caso do Enade, pela indicaçấo da qualidade de cursos de graduaçăo, haja vista ser um instrumento de avaliaçấo trienal que conceitua, na escala de 1 a 5, o desempenho de ingressantes e concluintes de graduaçóes, por meio de uma prova de formaçăo geral e específica ${ }^{8}$. Por conseguinte, o quarto decorre do terceiro, ao delimitar para as monografias defendidas no triênio 2009-2011, por ser o período cíclico de avaliaçăo corresponde à última divulgaçâo do exame, em 2011, ao tomar como referência o ano de início da presente pesquisa em recorte, 2012.

Os dados coletados foram caracterizados a partir de um código alfanumérico para identificar as monografias de Letras (ML-1, ML-2 e ML-3), bem como as de Ciências Sociais (MCS-1, MCS-2 e MCS-3). Cada objeto de análise está representado na Figura 1, que reúne informaçôes referentes ao curso, ao número de ordem de apresentaçâo e ao título:

Figura 1: Das monografias selecionadas para análise

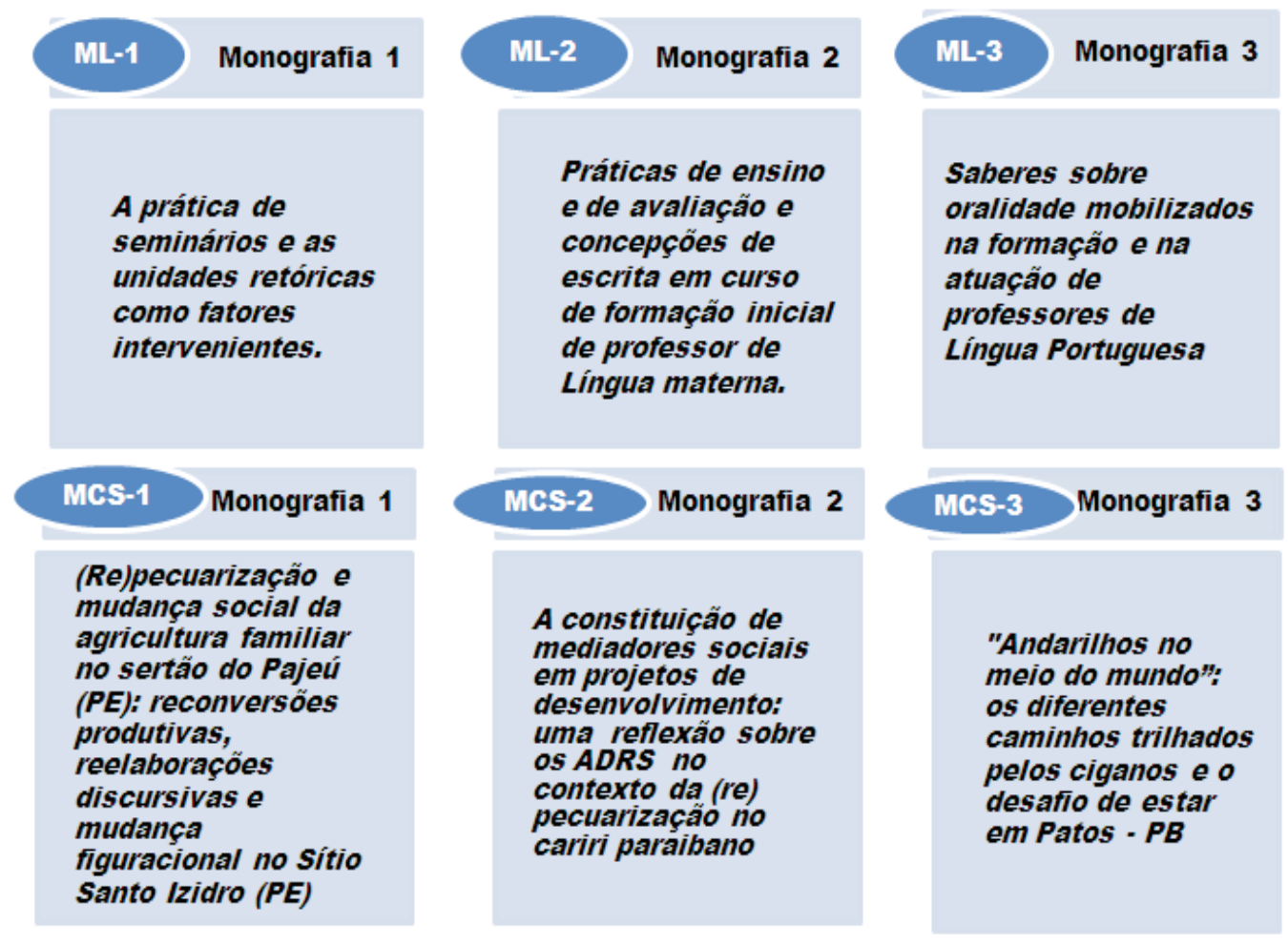

Fonte: SOUZA (2014)

Os respectivos títulos, na Figura 1, evidenciam temáticas que se assemelham, demonstrando particularidades de produçấo de conhecimento das comunidades

8 De acordo com o portal do Instituto Nacional de Estudos e Pesquisas Educacionais Anísio Teixeira (INEP): http://portal.inep.gov.br/indice-geral-de-cursos. Acesso em: 27 maio 2013. 
acadêmicas de pertença. As três monografias de Letras têm em comum o interesse em investigar formaçâo do professor. ML-1 e ML-2 se preocupam com a formaçăo inicial que perpassa o Curso de Licenciatura Plena em Letras, da UFCG; fazem isso através da interpretaçăo de dados advindos da disciplina Prática de Leitura e Produçâo de Textos - II (PLPT-II). ML-1 analisa seminários apresentados no período de 2010.2, considerando que possibilitam aos seminaristas - tidos como alunos da disciplina e professores em formaçăo - o ensaio de práticas docentes, como o desenvolvimento de estratégias e atitudes próprias da desenvoltura oral em sala de aula. Por sua vez, ML-2 analisa a prática docente de duas professoras formadoras, observando o ensino, a avaliaçấo e as concepçōes de escrita das formadoras que lecionaram a referida disciplina em períodos distintos, 2008.1 e 2009.1.

Semelhantemente a ML-1, ML-3 também investiga formaçăo do professor e oralidade. Desenvolve uma análise que reflete o estudo/ensino da oralidade a partir de graduandos de Letras da UFCG e da Universidade Estadual da Paraíba, assim como de professoras egressas destas instituiçóes, atuantes no Ensino Fundamental II. Preocupa-se com a formaçăo de estudantes de Letras para a oralidade e com o trabalho com essa prática nesse espaço de atuaçăo.

Dadas as caracterizaçôes, por amostragem, as monografias de Letras indicam preocupaçáo com questóes relacionadas à língua(gem) - no caso, escrita e oralidade - e à atuaçâo profissional diante destas questōes - formaçáo do professor, mobilizaçáo de estratégias na execuçăo de seminários e avaliaçăo. Săo preocupaçóes diferentes das três monografias de Ciências Sociais que, em geral: I) partem de problemas sociais e os relacionam a consideraçōes teóricas reconhecidas na literatura; e II) assemelham-se metodologicamente por terem realizado pesquisa de campo, com vistas à observaçăo e descriçấo de aspectos e comunidades sociais.

De modo mais específico, MCS-1 se contrapóe à problemática de que a pecuária no semiárido é vista de modo estático, advindo de uma inevitabilidade histórica. Com base nisso, analisa mudanças na agricultura familiar a partir de um processo de (re) pecuarizaçăo na área do Sítio Santo Izidro, no município de Săo José do Egito (PE) e no Assentamento da Barriguda, no município de Tuparetama (PE). Por seu turno, MCS-2 analisa como a mediaçăo social está ligada às estratégias de efetivaçấo, como a da caprinocultura, do atual modelo de desenvolvimento no Cariri Paraibano; e MCS-3 analisa a constituiçăo da identidade cigana a partir dos ciganos que vivem na cidade de Patos (PB).

Apesar das especificidades quanto à temática, as seis monografias coletadas têm características em comum, ao revelarem o papel dos sujeitos que participam do processo de produçâo: I) graduando que realiza trabalho de monoautoria; II) professor especialista que o orienta, tendo titulaçăo de doutor, haja vista ser uma exigência institucional do PIBIC; e III) professor especialista em dada área que avalia o trabalho.

As monografias revelam, também, uma produçăo em situaçâo espaço-temporal. Em se tratando do espaço, tanto se considera o institucional - seja do Curso de Licenciatura Plena em Letras, da Unidade Acadêmica de Letras, seja do Curso de Bacharelado em Ciências Sociais, da Unidade Acadêmica de Sociologia. Em se tratando do tempo, as monografias foram defendidas publicamente no período 2009-2011. Logo, a caracterizaçăo de dados apresentada possibilita compreender que as monografias de Letras 
e de Ciências Sociais têm elementos em comum que situam o gênero, mas também apresentam diferenças quanto ao modo de se fazer ciência.

\section{PERSPECTIVAS DE GÊNEROS EM CONTEXTO ACADÊMICO}

Os gêneros transitam em práticas sociais constituindo situaçôes comunicativas. Em cursos de graduaçāo, por exemplo, esquemas, fichamentos ${ }^{9}$, roteiros, resumos, comentários, seminários, provas, resenhas, análises literárias, ensaios, debates, projetos de pesquisa, relatórios, relatos, projeto monográfico, artigos de pesquisa e monografia validam a aprendizagem de graduandos do primeiro ao último período.

Gêneros como estes de contexto acadêmico têm despertado o interesse de pesquisadores, notoriamente depois de Swales (1990), principal representante da teoria de gêneros oriunda do Inglês para Fins Específicos. Esta obra de 1990 é um marco teórico que enfoca o estudo e ensino de variedades especializadas do inglês acadêmico, além de marcar a teorizaçăo e o desenvolvimento de metodologia para análise de gêneros em situaçấo de pesquisa e de ensino.

A obra apresenta os três principais e inter-relacionados conceitos, rediscutidos em estudos posteriores: a) comunidades discursivas, como "redes sociorretóricas" com objetivos comuns e propósitos comunicativos compartilhados; b) propósito comunicativo, enquanto uma propriedade privilegiada do gênero e a principal característica para afirmaçâo do pertencimento de um texto a dado gênero; e a clássica definiçâo de c) gêneros como uma classe de eventos comunicativos, através da qual membros de comunidades discursivas realizam propósitos comunicativos compartilhados 10.

Na clássica definiçấo, gêneros sâo concebidos como classes de eventos comunicativos e deles diferenciados, uma vez que estes podem ser aleatórios, idiossincráticos e motivados por um propósito único e distintivo. Além disso, săo como açōes linguísticas retóricas, que possibilitam à linguagem comunicar algo a alguém, para algum propósito, em momento e contexto específicos, por isso, sâo tidos como importantes ferramentas de ensino.

A partir da definiçâo apresentada, o autor trabalha a noçáo de prototipicidade, através da compreensăo de que protótipos de gêneros săo reconhecidos por uma lógica subjacente capaz de influenciar e restringir a escolha de conteúdo e estilo em contexto situado. Segundo o linguista, o reconhecimento dos protótipos é um dos procedimentos que um analista deve seguir, em um percurso que parte do contexto para o texto e projeta a organizaçáo de gêneros em movimentos retóricos e, consequentemente, seus aspectos textuais e linguísticos.

O percurso analítico que Swales tracejou é representado pela contribuiçăo metodológica de análise do conhecido modelo CARS (Criando um espaço de pesquisa), exposto a seguir, na Figura 2:

\footnotetext{
$9 \quad$ Sabemos que em manuais de Metodologia Científica, por exemplo, em Lakatos e Marconi (2001), o fichamento é tido como uma técnica de estudo. No entanto, compreendermo-lo, a partir da teoria de Swales (1990; 2004), como um gênero, por ser uma açăo linguística retórica que possibilita aos membros do contexto de que faz parte a realizaçâo de propósitos comunicativos.

10 Um gênero compreende uma classe de eventos comunicativos, cujos membros compartilham um conjunto de propósitos comunicativos. Estes propósitos săo reconhecidos pelos membros especialistas da comunidade de discurso e, desse modo, constituem a fundamentaçăo do gênero. (SWALES, 1990, p. 58).
} 
Figura 2: Modelo CARS para introduções de artigos de pesquisa

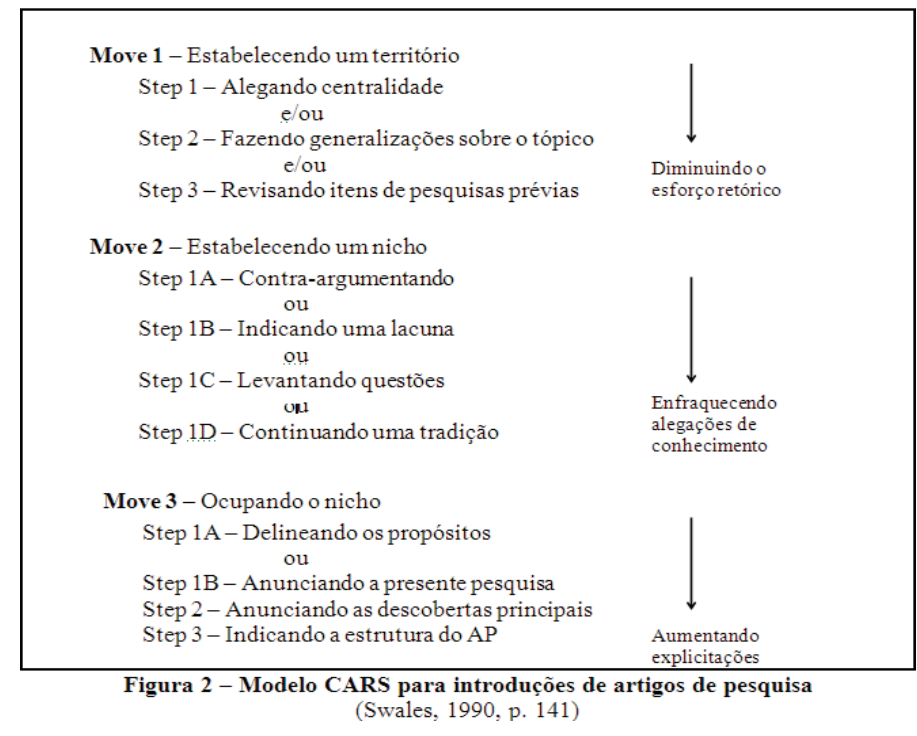

Fonte: SWALES, 1990, p. 141

O modelo CARS resulta da análise de 110 artigos de pesquisa (AP) - de física, educaçấo e psicologia - e contempla a organizaçâo retórica das respectivas introduçôes dos AP, em que se observou a realizaçăo de três movimentos. Sâo eles: 1. Estabelecendo um território; 2. Estabelecendo um nicho; e 3. Ocupando o nicho.

No modelo, cada movimento é entendido como unidade retórica que possibilita a realizaçăo de propósitos, através de steps - compreendidos como estratégias retóricas - que se relacionam para o cumprimento do propósito do gênero. Os movimentos e as estratégias apresentados resultam de uma observaçăo sistemática que considerou a frequência com que ocorrem nas introduçōes de AP.

Na medida em que o modelo proporciona o desenvolvimento de pesquisas diversas, sobretudo, acerca de produçăo acadêmica, também sofre críticas por causa, principalmente, do caráter aplicacionista de instrumentalizar a produçăo de gêneros. No congresso de Gêneros, em 2012, no Canadá, o próprio Swales admite o recebimento de críticas negativas ao trabalho de 1990, como as de Ann Johns de que gêneros no ESP são abordados como enquadres estáticos e fixos.

Johns (1997 apud BAWARSHI; REIFF, 2013 [2010], p. 72) defende a participação dos sujeitos na produçăo dos gêneros, de modo que estudantes que precisam produzi-los necessitam assumir-se como etnógrafos, para que apreendam gêneros em seu contexto acadêmico. Johns (2002 apud BAWARSHI; REIFF, 2013 [2010], p. 72) advoga que estudantes ${ }^{11}$ precisam atuar como pesquisadores e teóricos de gêneros, para que estes sejam compreendidos em sua complexidade e dinamicidade.

Berkenkotter e Huckin (1995) criticam a ineficiência do ESP para promover o entendimento das funçōes de um gênero, considerando a necessidade de que sujeitos

11 Tais estudantes que deveriam desenvolver uma postura autoetnográfica na escrita de gêneros sâo de um curso em Inglês para fins acadêmicos. 
assumam o papel de agente, que usam gêneros em suas práticas sociais. A crítica apresentada aponta as taxionomias, esquemas classificatórios e generalizaçóes dos estudos sobre gêneros de abordagem sociorretórica.

Askehave e Swales (2001) questionam a pouca importância atribuída às categorias discursivas dos gêneros, ao terem sido assinalados como eventos sociais e comunicativos; questionam, especialmente, o propósito comunicativo como a sua principal característica, pela desconsideraçăo de poder haver propósitos distintos em um mesmo gênero.

Diante dos questionamentos, percebemos que as críticas difundidas năo conseguiram invalidar o Modelo Cars, dado que sua aplicaçăo socialmente passiva năo seria culpa do modelo em si, mas decorrência dos agentes que trabalham com ele. Isto porque a proposta dos estudos de abordagem sociorretórica năo é cristalizar gêneros, porém é descrever sua funcionalidade textual, mostrando suas estratégias linguísticas mais recorrentes, a fim de que sujeitos tenham um material norteador para a produçăo deles. No mais, as críticas difundidas proporcionaram debates e revisóes profícuas nestes estudos.

Dada a necessidade de revisăo da noçăo de gênero, Swales (2004) apresenta um conceito mais flexível, assumindo que a definiçấo de 1990 é falha porque desconsidera a capacidade de criaçăo de gêneros novos. A flexibilidade consiste em definiçôes metafóricas de gêneros, por meio de uma perspectiva multifacetada, situando-os nas circunstâncias em que ocorrem12, conforme sintetiza com Metáforas sobre gêneros, exposta na Figura 3:

Figura 3: Metáforas sobre gêneros

\begin{tabular}{|lll|}
\hline Metáforas & Implicações \\
Frames para a ação social & $\longrightarrow$ & Princípios orientadores \\
Padrões de linguagem & $\longrightarrow$ & Expectativas convencionais \\
Espécies biológicas & $\longrightarrow$ & Historicidades complexas \\
Famílias e protótipos & $\longrightarrow$ & Conexões variáveis com o centro \\
Instituições & $\longrightarrow$ & Contextos modeladores; papéis \\
Atos de fala & $\longrightarrow$ & Discursos direcionados
\end{tabular}

Fonte: SWALES, 2004, p. 68 apud BEZERRA, 2006, p. 51

A Figura 3 sintetiza concepçôes metafóricas sobre gêneros, compreendidos como: a) açâo social, quando orientam açóes retóricas efetivas; b) padróes de linguagem, ao convencionarem o que é social e retoricamente apropriado; c) espécies biológicas, por situarem as mudanças funcionais em uma linha de tempo passado, presente e futuro; d) família e protótipos, pelo fato de se transformarem, podendo compartilhar e adquirir

12 Depois de dez anos, tendo em conta todos os diversos escritos sobre gênero na última década, estou menos otimista sobre o valor e a viabilidade de tais definiçôes. Por um lado, eles năo conseguem competir com o imperativo categórico kantiano de ser verdadeiro em todos os mundos possíveis e em todos os momentos possíveis; por outro lado, a adoçâo ou as definiçóes fáceis podem nos impedir de compreendermos gêneros recentemente explorados ou emergentes. Pelo contrário, acredito que temos de caracterizar gêneros como um esforço metafórico, essencialmente, para que as várias metáforas possam ser chamadas em proporçôes variadas, de acordo com as circunstâncias, a sua própria luz em nossos entendimentos. (SWALES, 2004, p. 61) 
características entre si; e) instituiçōes, através de processos de produçăo e recepçăo típicos, formados em uma rede de gêneros e valores que os sustentam; e f) atos de fala, por meio do desempenho de agentes em discursos direcionados, mais recorrentes em monólogos e poemas.

Ao definir gêneros através de metáforas, o autor defende que as várias formas de compreendê-los devem ser aceitas, porque cada procedimento metafórico resguarda especificidades relevantes. A visáo mais flexível apresentada também reconsidera as noçóes de propósito comunicativo e comunidade discursiva, admitindo-se que um gênero pode ter mais de um propósito, de modo que para um analista é recomendado iniciar com a consideraçấo de um propósito oficial da visăo de especialista e ir repensando tal propósito ao passo em que estuda o contexto do gênero e o entendimento que se têm sobre ele.

As críticas recebidas pelo trabalho de 1990 também levam Swales a rever o conceito de comunidade discursiva, apresentando-a através de uma concepçăo mais dinâmica, com pressuposiçôes ocultas e intuiçôes sutis que unem pessoas em grupos sociais. Swales (2009 [1992]) apresenta seis novos critérios para o conceito, para que representem um mundo mais complexo:

1) [Comunidade discursiva] possui um conjunto perceptível de objetivos. Esses objetivos podem ser formulados pública e explicitamente e também ser, no todo ou em parte, aceitos pelos membros; podem ser consensuais; ou podem ser distintos, mas relacionados (velha e nova guardas; pesquisadores e clínicos, como na conflituosa Associaçăo Americana de Psicologia).

2) possui mecanismos de intercomunicaçăo entre seus membros. (năo houve mudança neste ponto; sem mecanismos, năo há comunidade).

3) usa mecanismos de participaçăo para uma série de propósitos: para prover o incremento da informaçâo e do feedback; para canalizar a inovaçăo; para manter os sistemas de crenças e de valores da comunidade; e para aumentar seu espaço profissional.

4) utiliza uma seleçấo crescente de gêneros no alcance de seu conjunto de objetivos e na prática de seus mecanismos participativos. Eles frequentemente formam conjuntos ou séries.

5) já adquiriu e ainda continua buscando uma terminologia específica.

6) possui uma estrutura hierárquica explícita ou implícita que orienta os processos de admissáo e progressáo dentro dela. (SWALES, 2009 [1992], p. 207-208)

Diante dos critérios reformulados, Swales (2009 [1992], p. 214) apresenta comunidade discursiva como uma rede de conexâo interdisciplinar. No entanto, afirma que as consideraçóes revistas ainda năo satisfazem, até porque "a 'verdadeira' comunidade discursiva pode ser mais rara e esotérica do que eu [ele] pensava" (SWALES, 2009 [1992], p. 206). Dadas as problemáticas em torno do termo comunidade, entendemos de maneira flexível a comunidade acadêmica onde se situam socioculturalmente os dados recolhidos para o presente estudo. É o espaço discursivo em que sujeitos se apropriam da produçáo acadêmica, sendo constituídos enquanto profissionais através do que produzem.

Por meio dos seis critérios reformulados, neste trabalho, compreendemos que comunidades acadêmicas, como as do Curso de Licenciatura Plena em Letras e do Curso de Bacharelado em Ciências Sociais, têm um objetivo público de graduandos produzirem monografia como pré-requisito para conclusăo do curso, como uma maneira de 
praticar mecanismos participativos. Nesse contexto, há uma hierarquia estabelecida, uma vez que a referida produçăo acontece em momento de conclusáo do curso, náo em fase em que se é neófito (novo membro).

Os seus sujeitos produtores de monografia poderiam ser considerados como membros experientes em suas comunidades acadêmicas de pertença, haja vista que, para a produçấo deste gênero, passaram por etapas anteriores de desenvolvimento da escrita acadêmica, em que adentram na academia, tentam se inserir e ser reconhecidos no meio, passam a pertencer a este contexto, até o momento em que seu trabalho de conclusăo de curso revela todo o percurso de aprendizagem. Entretanto, mesmo que concluintes em seus cursos de graduaçăo, săo iniciantes no fazer-científico. Por conseguinte, por representatividade, o sujeito se sente membro na monografia de especializaçăo; é membro iniciante na dissertaçăo de mestrado; é membro intermediário na tese de doutorado e é membro experiente quando é considerado pesquisador pelo CNPq.

A partir desse enfoque swalesiano discutido, trabalhos diversos sobre gêneros foram e vêm sendo desenvolvidos, dentre os quais os de pesquisadores brasileiros, conforme divulgado em Bawarshi e Reiff (2013 [2010]). Em meio a vários trabalhos, como outros em Biasi-Rodrigues et alii (2009), destacam-se os que analisam a estrutura retórica de: abstracts de artigos científicos (MOTTA-ROTH; HENDGES, 1996; RAMOS, 2004; 2011; SANTOS, 1995, 1996); resumos de dissertaçōes (BIASI-RODRIGUES, 1998); e resenhas (ARAÚJO, 1996; BEZERRA, 2001; MOTTA-ROTH, 1995).

Destaca-se, também, a tese de Bezerra (2006), em que analisa gêneros introdutórios em livros que circulam na academia e defende a importância da análise dos gêneros na sua inter-relaçấo com outros textos, como uma maneira de compreender as práticas que determinam e sâo determinadas pelas comunidades discursivas. Mais recentemente, Ritti-Dias e Bezerra (2014) verificaram, através do Modelo CARS, a organizaçāo retórica de introduçóes de artigos científicos da área de saúde pública, confirmando todos os movimentos retóricos propostos por Swales (1990). Os autores comprovam que o reconhecido marco teórico-metodológico swalesiano continua tendo a importância de orientar analistas de gêneros. Além do atual potencial analítico, acrescentamos que o modelo também tem o devido valor de nortear alunos e profissionais na produçâo de gêneros.

Pensando nas contribuiçóes desde Swales (1990), buscamos entender o contexto sociorretórico em que monografias se encontram para, depois, compreender sua organizaçăo retórica, particularmente, em seu texto de introduçăo. Nesse percurso, sabemos que nossos dados coletados revelam açóes retóricas tăo complexas quanto as apresentadas através das introduçóes de artigos de pesquisa, no modelo CARS. Com isso, adotamos as releituras do enfoque swalesiano, em Askehave, Swales (2001), Swales (2004) e Bhatia, (2004; 2009 [1997]).

\section{DOS ESTUDOS TÉCNICO-CIENTÍFICOS À AÇÃO SOCIORRETÓRICA: $O$ GÊNERO EM FOCO}

O gênero monografia resulta de um trabalho de pesquisa em fase de iniciaçấo do fazer científico, de modo que as particularidades desse fazer se relacionam à produçâo escrita em que é oficializado. Sua linguagem se constitui em conhecimento científico, que se estabelece na busca de incompletudes teórico-empíricas a serem questionadas. 
Ao questioná-las, acaba enfrentando práticas sociais por vezes convencidas da soberania científica, mas na lida com aversōes, estabelece território de aceitaçăo, através de trabalhos outros de cunho científico. Longe da resistência que engessa a epistemologia, Bachelard (1996) defende que a cultura científica deve partir de um conhecimento aberto e dinâmico, caracterizado como científico através da existência de um problema, para o qual se busca apresentar resposta.

No caso das monografias coletadas, o fato de serem do Centro de Humanidades indica o respectivo paradigma de pensamento vigente. Nesse contexto, por exemplo, têm em comum a preferência metodológica de desenvolver pesquisas qualitativas, por meio de método indutivo. Além disso, por terem sido escritas por bolsistas do PIBIC, programa institucional que visa à formaçâo científica, revelam os interesses investigativos de sujeitos que participaram deste programa e, consequentemente, dos Cursos de Licenciatura Plena em Letras e Bacharelado em Ciências Sociais.

No seu caráter científico, as monografias sâo gêneros produzidos em graduaçôes e especializaçôes. Quanto à sua natureza de produçâo, sâo trabalhos monoautorais e monotemáticos, apresentados em fase conclusiva da graduaçăo ou de pós-graduaçăo latu senso, com o poder institucional de autorizar o recebimento do título de graduado ou de especialista. No contexto em que se encontram, utilizam-se de ferramentas como os preceitos da Associaçăo Brasileira de Normas Técnicas (ABNT) e de manuais de metodologia científica.

Essas ferramentas técnico-científicas evidenciam conhecimentos superficiais e formais quanto à natureza do trabalho monográfico, propiciando confusăo acerca do que săo monografias, dissertaçóes e teses. Por exemplo, embora Lakatos e Marconi (2001, p. 150) considerem a monografia como o passo principiante da atividade científica do pesquisador, os autores dividem-na em três tipos, seguindo uma ordem crescente de dificuldade, originalidade, profundidade e extensăo de produçâo, quais sejam: monografia, dissertaçâo e tese.

Por sua vez, Oliveira (2002) afirma que

O uso do termo monografia, de forma generalizada para designar todo o tipo de trabalho confeccionado, durante a realizaçăo do curso de graduaçăo, ainda que a base seja uma investigaçăo científica, é incorreto.

Monografia significa a abordagem de um único assunto, ou problema, sob tratamento metodológico de investigaçáo. Exige, portanto, que lhe seja dada especificaçăo, um tratamento aprofundado e exaustivo, que năo deve ser confundido com extensăo. (OLIVEIRA, 2002, p. 236)

Apesar de este autor reconhecer particularidades năo encontradas em outros trabalhos de investigaçăo científica, igualmente conclui, no decorrer do seu texto, que dissertaçấo e tese săo tipos de monografia, dada a natureza de investigarem um dado problema à luz de um enfoque metodológico.

Também superficialmente, a ABNT apresenta uma definiçấo de trabalhos acadêmicos:

trabalho de conclusáo de curso de graduaçăo, trabalho de graduaçăo interdisciplinar, trabalho de conclusáo de curso de especializaçáo e/ou aperfeiçoamento;

documento que apresenta o resultado de estudo, devendo expressar conhecimento do assunto escolhido, que deve ser obrigatoriamente emanado da disciplina, módulo, estudo independente, curso, programa, e outros ministrados. Deve ser feito sob a coordenaçáo de um orientador (ASSOCIAÇĀO BRASILEIRA DE NORMAS TÉCNICAS, 2011, p. 4). 
Pela ABNT (2011), monografias podem ser de naturezas diversas, ocupando os seguintes eventos de conclusăo: de graduaçăo, graduaçăo interdisciplinar, especializaçăo e aperfeiçoamento. Confirmando essa apresentaçăo superficial, o referido documento normatiza a organizaçâo estrutural dos ditos trabalhos acadêmicos (as monografias), das teses e dissertaçōes em: elementos pré-textuais, elementos textuais e elementos pós-textuais. A escrita desses três tipos de trabalhos é apresentada a partir de uma norma a ser seguida, desconsiderando as particularidades deles e os encaixando em formas prontas para ser usadas.

No entanto, abordagens superficiais, como as da ABNT e das orientaçôes de guias de metodologia científica, năo garantem a produçăo do gênero monografia, por uma série de fatores externos, tais como cognitivos e sociais, que náo săo contemplados. Neste particular, tais abordagens tornam a referida produçáo angustiante para o graduando, que se depara com várias normas a serem obedecidas em um limite entre 30 e 50 páginas.

Abordagens como estas nos remetem à discussão em Swales (1990) sobre a atençâo a ser acrescida às nomenclaturas atribuídas aos gêneros por profissionais mais familiarizados com seu meio de atuaçăo, porque acaba se sobressaindo a açăo retórica à concepçáo do gênero:

\begin{abstract}
No que diz respeito aos gêneros acadêmicos, muitos, se năo a maioria, săo termos que incorporam uma pré-modificaçăo de nome ou propósito: palestra introdutória, exame de qualificaçăo, artigo de pesquisa, revisăo de sessăo e oficina de escrita. Outros invertem a ordem usando um nome determinado intencionalmente: concessáo de aplicaçâo, reimpressâo de descriçâo de pedido e curso. Ainda, outros indicam a ocasiăo, em vez do propósito comunicativo, tais como o exame final, palestra de plenária, ensaio de homenagem, encontro da faculdade ou reuniáo de graduaçăo. (Swales, 1990, p.55. Grifos nossos).
\end{abstract}

Pelo que Swales (op. cit) discute, os profissionais, considerados como mais experientes, apresentam nomeaçóes para os gêneros a partir dos propósitos, das orientaçóes e das ocasiōes a que servem, demonstrando uma ação sociorretórica evidente. Por exemplo, em um dado evento em que ocorram palestras, é notório que alguém irá proferir a palestra de abertura, sendo óbvia a nomeaçâo do gênero como palestra de abertura.

Segundo o autor, tais nomeaçóes inequívocas demonstram uma açăo constrangedora para os que nâo estăo familiarizados com determinados eventos comunicativos, porque năo teriam o conhecimento das práticas sociais que mobilizam. Quando profissionais nomeiam um gênero como exame de qualificaçâo, para um neófito em contexto acadêmico, eles provocam desconforto, por este năo ter a vivência da ocasiăo reportada na nomeaçăo. Neste ponto, uma dissertaçăo pode ser produzida para um exame de qualificaçâo, mas o gênero em si nâo equivale à ocasiấo de qualificaçáo. De modo análogo, apresentar uma monografia como uma produçáo de monoautoria pode causar desespero, pela nâo vivência da ocasiāo e dos propósitos a ele referido.

Problemas nesta concepçăo a partir da açăo sociorretórica nos fazem pensar sobre o fato de que monografia, dissertaçâo e tese sâo nomeadas nos estudos técnicocientíficos mencionados pelas funçōes que desempenham: trabalho monotemático, monoautoral, dissertativo e trabalho de elaborar uma tese, esta compreendida como um conceito encontrado, em decorrência de um trabalho sistemático que revela o ponto de vista de alguém. 
Estes trabalhos têm características compatíveis, porque tanto săo produzidos na realizaçăo de pesquisa, quanto com um propósito similar de ser requisito parcial para o cumprimento de dado curso, resultando no recebimento de um título correspondente. Năo obstante, tais trabalhos evidenciam particularidades que demonstram ser gêneros diferentes, năo apenas porque săo produzidos em contextos distintos, mas, inclusive, pelo motivo de o próprio contexto implicar diferenças discursivas e linguístico-textuais.

Com base nisso, consideramos monografias através de suas características discursivas, linguístico-textuais e do propósito oficial de validar uma graduaçăo cursada. Assim, monografia é um gênero socialmente aceito como condiçăo para o recebimento do título de graduado, expondo seu nível de competência profissional, atestando a credibilidade de professores especialistas - orientador e arguidor - e do Curso como um todo - com demais professores e a coordenaçâo.

Do contexto acadêmico, consideramos monografias a partir de um contínuo de produçōes que iniciam o estudante no meio científico. Iniciaçāo esta oriunda, por vezes, da leitura de teorias, pesquisa, estudos de outrem; por outro lado, advinda da escrita do graduando, da maneira como apresentamos na Figura 4, através de uma analogia com as "representaçôes do contínuo dos gêneros textuais na fala e na escrita" (MARCUSCHI, [2001] 2010, p. 41):

Figura 4: Representação do contínuo de gêneros na graduação

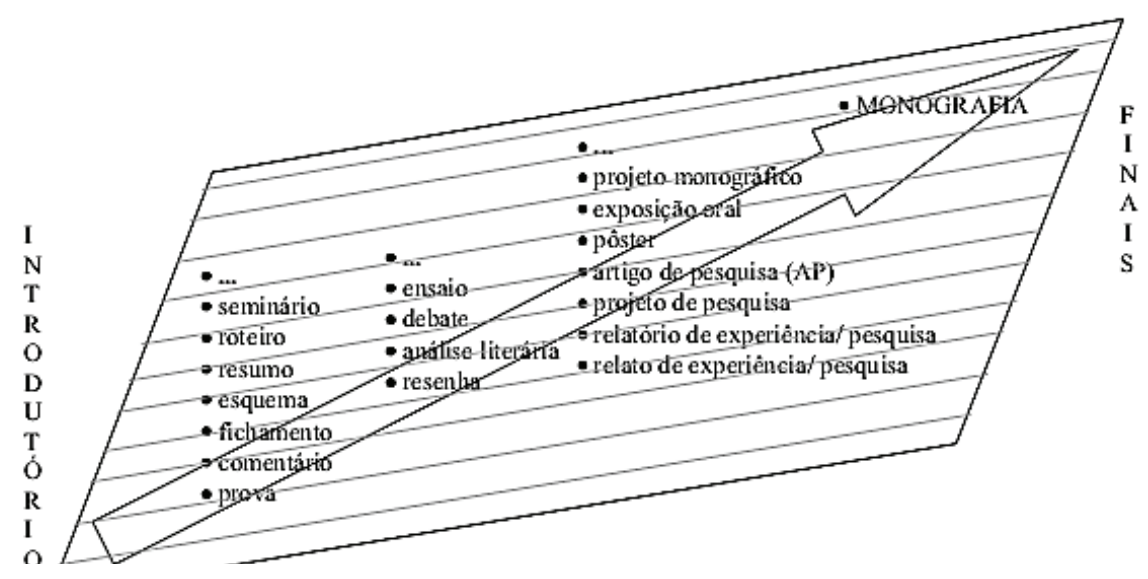

Fonte: Elaborada pelas autoras, retextualizada de Marcuschi ([2001] 2010)

A Figura 4 representa a ocorrência dos variados gêneros em cursos de graduaçăo. Oferece amostragem que vai dos gêneros introdutórios aos finais nesse nível acadêmico, em uma seta inclinada ascendente que simula o contínuo existente entre tais gêneros. Apresenta-os a partir de uma posiçấo hierárquica, em que quanto mais distante da base de cada fase apresentada, maior a dificuldade para a fase em que se encontra; e quanto mais próxima do topo da seta, maior a autonomia acadêmica esperada.

De modo geral, sâo apresentados em quatro fases inter-relacionadas, conforme os pontilhados expostos, de ensino/aprendizagem. Săo elas: I. A inicial, com os gêneros concebidos como os topicalizados (esquema, fichamento, roteiro etc.), os expositivo-descritivos (resumo etc.) e os expositivo-descritivo-apreciativo-introdutórios (comentário, seminário, 
prova etc.); II. A intermediária, desenvolvida no percurso da interaçăo com o ambiente acadêmico (resenha, análise literária, ensaio, debate etc.); III. A introdutório-científica, que demonstra inserçâo com práticas de pesquisa (relato de experiência/ de pesquisa, relatório de experiência/ de pesquisa, projeto de pesquisa, artigo de pesquisa, pôster, exposiçâo oral, projeto monográfico etc.); e IV. A conclusiva (monografia).

O contínuo estimado assinala a flexível situabilidade dos gêneros, em conformidade ao que é assegurado por Berkenkotter e Huckin (1995), ao compreenderem que os gêneros se situam cognitivamente e continuam seu desenvolvimento à medida que participamos de atividades no ambiente de cultura13. Com este respaldo, a ilustraçâo exposta representa que os gêneros em foco săo produzidos em momentos distintos de uma graduaçăo, porém seu ensino e sua aprendizagem se centram em momentos específicos. Esboça que a monografia náo necessariamente é produzida no fim de dado curso e que dela se espera a produçâo prévia de outros gêneros, como os expostos na Figura 4 - além de outros possíveis, năo apresentados neste momento, a exemplo dos gêneros oclusos pesquisados por Swales (2004), indicados na ilustraçăo pelo sinal de reticências.

Em síntese, a ilustraçâo aponta para um processo que permeia uma série de gêneros apre(e)ndidos no curso de graduaçăo, situando a monografia na fase conclusiva do curso. Nessa perspectiva cultural, as monografias em análise revelam esse contínuo em um histórico de agrupamento de projetos de PIBIC, como aglutinador. Por exemplo, nas introduçōes delas, há uma mescla de gêneros, como: o relatório de momentos anteriores relativos ao PIBIC, bem como uma súmula de um projeto prévio de pesquisa e de tema lido em outro produto acadêmico, da maneira como as suas citaçóes comprovam os diversos intertextos retomados.

Em termos de Swales (2004), a Ilustraçăo 4 revela uma rede de gêneros, considerando que os gêneros nela apresentados se dispóem em relaçôes intertextuais, que permitem aos neófitos do contexto acadêmico de graduaçâo uma visualizaçâo do processo de produçâo de monografias. A ilustraçăo revela, ainda, uma hierarquia de gêneros, já que os gêneros apresentados têm valores diferenciados em contexto acadêmico, indicando que alguns săo mais prestigiados, como é o caso de monografias, que tem o poder de autorizar o recebimento da titulaçăo de graduado.

Nesse contexto, a monografia é um dos gêneros que pode ocupar o evento trabalho de conclusâo de curso (TCC). Todavia, a depender do curso, da instituiçấo, do meio em que se encontre, o TCC pode ser constituído por gêneros outros, como o artigo de pesquisa (AP). Diante dessa possibilidade de escolha, graduandos podem optar por um gênero que comunica especificamente neste contexto de conclusâo de graduaçáo ou por outro ensinado/ aprendido para concluir dada disciplina, para divulgar pesquisa em congressos, para ser publicado em anais, revistas, periódicos ou em livros. Portanto, o gênero monografia indica progressăo no contínuo dos gêneros acadêmicos, visto que através deste, vários outros sâo desencadeados, inclusive um AP. Melhor dizendo, de uma monografia podem decorrer múltiplos AP, escritos para que a pesquisa desenvolvida seja divulgada e depois, de sua apresentaçăo, para tornar públicos os resultados obtidos.

13 Situabilidade. Nosso conhecimento de gêneros é derivado e incorporado em nossa participaçăo nas atividades comunicativas da vida diária e profissional. Como tal, o conhecimento de gênero é uma forma de "cogniçấo situada" que continua a se desenvolver quando participamos das atividades culturais. (BERKENKOTTER; HUCKIN, 1995. p. 4. Grifos dos autores). 
Pelas discussóes apresentadas, com base em Swales (1990; 2004), entendemos que o gênero monografia mobiliza açôes sociorretóricas e possibilita aos membros do contexto de que fazem parte a realizaçăo de propósitos comunicativos, como o de validar um curso de graduaçăo e legitimar a permissăo institucional para se continuar pesquisas em pós-graduaçôes. Comungando com o posicionamento de Swales (2004) de que gêneros devem ser definidos metaforicamente, a depender das circunstâncias ocasionadas, em Souza (2014), abordamos outras descriçōes de monografias através do seu funcionamento discursivo-textual. Em suma, o referido gênero é uma açăo social, da maneira como apresentamos, bem como é um ato textual-discursivo, segundo analisamos no tópico seguinte.

\section{A AÇÃO TEXTUAL DE INTRODUZIR O GÊNERO MONOGRAFIA}

A escrita identifica as instituiçôes sociais pelas regras, códigos de conduta e convençôes linguísticas que estabelecem, conforme entendemos com Coulmas (2014). A linguagem institucional segue um estilo ossificado, empolado e pomposo que resiste às inovaçōes das variedades informais, associa-se a uma variedade particular de língua escrita e constitui a comunidade das letras. Espaços sociais como universidades têm poder socialmente reconhecido que, assim como a sociedade moderna, se baseiam na dissociaçấo da palavra e do falante por meio da escrita. Nestes espaços, a produçâo de monografias acontece em estruturas esquemáticas prototípicas em seu contexto de açáo, contemplando a criatividade de seus sujeitos produtores, sua capacidade sociocognitiva de produzir gêneros e, nada obstante, potencializando seu ambiente institucional.

Tais estruturas esquemáticas săo tratadas por nós em prol de propósitos comunicativos específicos evidenciados no gênero monografia, relacionando-os ao o quê a tradiçấo denomina de elementos estruturais de trabalhos científicos, da maneira como expomos no Quadro 1:

Figura 5: Visão geral da organização retórica de monografias

\begin{tabular}{|c|c|}
\hline Elementos estruturais & Propósitos comunicativos \\
\hline $\begin{array}{l}\text { Elementos pré-textuais } \\
\text { Capa (obrigatório), lombada (opcional), folha de rosto } \\
\text { (obrigatório), errata (opcional), folha de aprovação } \\
\text { (obrigatório), dedicatória(s) (opcional) (is), agradecimento(s) } \\
\text { (opcional) (is), epígrafe (opcional), resumo na lingua } \\
\text { vernácula (obrigatório), resumo em língua estrangeira } \\
\text { (obrigatório), lista de ilustrações (opcional), lista de tabelas } \\
\text { (opcional), lista de abreviaturas (opcional), lista de símbolos } \\
\text { (opcional) e sumário (obrigatório). }\end{array}$ & SITUAR A PESQUISA \\
\hline \multirow[t]{2}{*}{ Elementos textuais } & INTRODUZIR A PESQUISA \\
\hline & FUNDAMENTAR TEORICAMENTE \\
\hline \multirow[t]{3}{*}{ Introdução, desenvolvimento e conclusão. } & RELATAR METODOLOGIA \\
\hline & ANALISAR DADOS \\
\hline & CONCLUIR A PESQUISA \\
\hline $\begin{array}{l}\text { Elementos pós-textuais } \\
\text { Referências (obrigatório), glossário (opcional), apêndice(s) } \\
\text { (opcional) (is), anexo(s) (opcional) (is) e índice(s) (opcional) } \\
\text { (is). }\end{array}$ & CREDENCIAR O TRABALHO \\
\hline
\end{tabular}

Fonte: SOUZA (2014) 
A ABNT e os manuais de metodologia científica normatizam os elementos composicionais de monografias, que apresentamos na primeira coluna do Quadro 1. Reconhecemos essa normatizaçấo e a constante consulta que graduandos fazem a estas referências no momento de produçấo de seus textos. Contudo, na busca do reconhecimento pelas produçóes no contexto acadêmico, as monografias sáo realizadas em determinados propósitos comunicativos que desempenham funçôes escritas situadas de organizar a estrutura esquemática do referido gênero, sem que para isso seja preciso delimitá-lo em sessóes textuais fixas, como faz a tradiçăo clássica.

Ao sabermos da existência de diferentes abordagens que subjazem às práticas de escrita, representamos no Quadro 1 uma que regulariza o produto textual e outra que processa a açâo textual e social de gêneros. Ao invés de considerarmos os elementos apresentados na primeira coluna, fazemos uma escolha teórico-metodológica de analisar as monografias pelos propósitos a que servem, depreendidos a partir de nossa análise, de: situar, introduzir, fundamentar teoricamente, relatar metodologia, concluir e credenciar (d)a pesquisa/ o trabalho. Na nossa dissertaçâo de Mestrado, discutimos o propósito de analisar dados, neste artigo, continuamos a descriçăo do gênero monografia a partir do seu propósito de introduzir a pesquisa.

Por meio de estudos de abordagem sociorretórica, especialmente de Swales (1990; 2004), Bhatia (2004; 2009) e de, no Brasil, Bezerra (2006) e Biasi-Rodrigues e Bezerra (2012), entendemos que propósitos comunicativos săo construçóes e açôes textuais diversas que caracterizam a organizaçăo esquemática de gêneros. Os propósitos săo depreendidos depois de várias análises de gêneros, assim, sua recorrência indica caminhos flexíveis e instáveis para produçóes textuais vindouras. No entendimento de que as açóes textuais acontecem em contextos socioculturais, os propósitos sâo múltiplos e compreendidos também de modo mais abrangente, como as açôes sociais decorrentes das várias situaçóes textuais. Dito de outro modo, os gêneros revelam propósitos comunicativos mais gerais, que indicam sua açăo social, e outros mais específicos, que constroem sua estrutura composicional.

No propósito de introduzir a pesquisa, há uma açăo textual específica no interior do gênero monografia. Para a apreciaçăo desta açăo nos nossos dados, partimos das análises de introduçóes acadêmicas, de livros, artigos e conferências, por exemplo, realizadas por Bhatia (2004) e Bezerra (2006), que se detêm aos propósitos comunicativos e aos movimentos retóricos que os realizam, sem a preocupaçáo swalesiana de especificar as estratégias retóricas em cada movimento. Bhatia (2004) discute que textos introdutórios têm propósitos múltiplos, como de introduzir uma pesquisa ou de promovê-la e que se organizam em, ao menos, movimentos retóricos que estabelecem um campo de estudo, identificam o tema de pesquisa, apresentam os métodos de pesquisa, delimitam dos objetivos de investigaçâo e apresentam os resultados e as conclusóes esperados. Através desta discussāo, Bezerra (2006) igualmente esquematiza as introduçôes acadêmicas pelos movimentos retóricos para: estabelecimento do campo de estudo, indicaçâo de lacuna a preencher no campo, informaçâo sobre a origem do livro, apresentaçâo/discussâo do conteúdo, indicaçâo dos objetivos do livro e agradecimentos. No caso das monografias que analisamos, também identificamos movimentos recorrentes, que ilustramos a seguir com excertos de uma das seis introduçôes das monografias analisadas. 
Propósito comunicativo: Introduzir a Pesquisa

O seminário surgiu na década de 30, como uma técnica de ensino socializado trazida pela Escola Nova, dentre as propostas de Dinâmica de Grupo. O movimento, surgido numa época de grandes mudanças políticas, sociais e econômicas, através do Manifesto da escolanovista, tinha fortes alicerces na Europa e na América, tendo na educação o único meio democratizador da sociedade, defendendo, pois, o direito à escola gratuita para todos. Entretanto, objetivava unicamente a transmissão do conteúdo, de forma a transformar o ambiente escolar em pequenas comunidades.

[...]. [continua tecendo considerações com revisão de literatura sobre seminários]. Apesar dessas orientações, o trabalho com seminário no âmbito do ensino de língua materna, em sua grande maioria, não desenvolve e/ou propõe uma utilização sistematizada, com objetivos específicos na sua aplicação. Tal afirmação é comprovada pelo que se verificou em dois manuais didáticos de língua portuguesa investigados no trabalho Análise linguística em gêneros orais formais ( $\mathrm{PIBIC/CNPq}$ 2009-2010). Esse estudo apontou para uma gama de gêneros orais a serem trabalhados em sala de aula: relato oral, diálogo, jogral, discussão oral, debate, entrevista, exposição oral e seminário, que não apresentaram uma abordagem sistemática, reduzindo o ensino do gênero à informalidade e à espontaneidade. A análise dos livros ressalta ainda a escassa sugestão de uso deste último, assim como da exposição oral, enquanto objeto de estudo, havendo ocorrência de apenas uma sugestão em cada coleção.

\section{[...]. [Segue descrevendo tais resultados].}

Essa constatação rompe com o propósito de ensino da linguagem oral em instâncias públicas, já que o seminário configura-se como instrumento importante de interação e desenvolvimento de atividades de leitura, exposição, escrita e debate, equivalendo as duas modalidades da língua na produção do evento comunicativo (KLEIMAN, 1995).

As atividades que se moldam nesta situação oral constroem um quadro de elementos regulares e complexos que contém o conteúdo informacional fundamental para o desenvolvimento temático e coerente do assunto proposto.

Nesse sentido, destacando as etapas mais ou menos padronizadas que o formam - planejamento, execução e avaliação -, é na execução, através das unidades retóricas, que o evento se materializa, contribuindo para uma didatização do conteúdo proposto e delimitando sua ocorrência numa determinada situação espaço-temporal e, o que, pois, constitui-se o objeto de estudo desse trabalho. Essas etapas estão interligadas e auxiliam a organização geral do evento comunicativo, recaindo sobre a hipótese de que unidades retóricas bem estabelecidas parecem ser determinantes para a mobilização do conteúdo, contribuindo para uma boa atuação dos sujeitos que o mobilizam (MATENCIO, 2001). Momentos como abertura contextualizada, problematizada e encadeada no processo de exposição, e fechamento, reflexivo e solucionador do problema inicial, concorrem para uma fase instrumental ideal na realização do objetivo com práticas discursivas, nesse caso, a prática de seminário.

\section{[...]. [Segue apresentando o objeto, com o suporte de orientações teóricas].}

Com esse pano de fundo, esta pesquisa pauta-se na investigação do tratamento dado ao seminário na formação inicial de professores de língua materna, buscando responder ao seguinte questionamento: "Qual a interferência das unidades retóricas na prática de seminário para a mobilização dos conteúdos?" Com esse pano de fundo, esta pesquisa pauta-se na investigação do tratamento dado ao seminário na formação inicial de professores de língua materna, buscando responder ao seguinte questionamento: "Qual a interferência das unidades retóricas na prática de seminário para a mobilização dos conteúdos?".

Centrando nosso estudo na observação, descrição e interpretação das unidades retóricas do seminário que possam vir a influenciar a execução e mobilização do conhecimento em sua aplicação, de modo específico, em uma turma da disciplina PLPT II (Prática de leitura e Produção de textos) do curso de licenciatura em Letras da Universidade Federal de Campina Grande (campus Campina Grande), no período letivo de 2010.2, objetivamos de maneira geral:

- Investigar a prática de seminários no âmbito da formação inicial do professor.

E de modo específico:

- Identificar e caracterizar as unidades retóricas constitutivas do seminário;

- Analisar as semelhanças e diferenças na construção de aberturas e fechamentos para a realização do evento. 
Propósito comunicativo: Introduzir a Pesquisa

A relevância da temática aqui enfocada é justificada pela constatação de que, apesar do evento em análise ser efetuado em vários momentos de escolaridade - ensino fundamental, médio e superior - registrado e orientado em livros didáticos (Projeto Araribá - português) e de metodologia de ensino (Vieira, 2007; Silva, 2007; Meira e Silva, 2010); pouca literatura é disponibilizada acerca de possibilidades de estudo dessa prática, e as propostas que se apresentam parecem não avançar ou garantir meios suficientes para que o mesmo seja realizado de maneira conscientemente satisfatória.

Além disso, por enquadrar-se no âmbito da exposição oral, o seminário caracteriza-se como um instrumento importante para apropriação da situação de sala de aula, uma vez que, os seminaristas, alunos de letras em formação inicial, têm a possibilidade de desenvolver estratégias, etapas e desenvolturas específicas da atuação oral em sala de aula.

Assim sendo, o presente trabalho desenvolve-se com base nas propostas de trabalho com oralidade formal (Schneuwly e Dolz, 2004), nas contribuições e concepções acerca de seminário (Bezerra, 2003; Vieira, 2007; e Silva, 2007), de unidades retóricas (Matencio, 2001; Bezerra, 2001; Antonio, 2002) e de mobilização de conhecimento (Halté, 2008; Petitjean, 2008; Rafael 2007; Xavier, 2009).

A presente monografia se divide em cinco partes, sendo a primeira esta introdução, três capítulos seguintes e as considerações finais.

No primeiro capítulo, traremos uma revisão bibliográfica acerca das teorias que fundamentam nossa pesquisa. [...]

No Capítulo dois, "Pressupostos metodológicos", procuraremos apresentar a metodologia utilizada para coleta e sistematização dos dados de análise. [...]

O capítulo três - "Análise de dados" - corresponde à apreciação das fases de abertura e fechamento, identificando, no item "Identificação das Unidades Retóricas", e analisando semelhanças e diferenças nos subtópicos, "As estratégias na fase de abertura" e "As estratégias na fase de fechamento",

Para finalizar, nas "Considerações Finais" apresentamos as conclusões obtidas [...].

ML-1 (pp. 8-12)
Movimentos

retóricos

Justificação da

pesquisa

Delineamento

teórico da

pesquisa

Apresentação

da estrutura organizacional da monografia

Por representatividade, favorecem a açăo do propósito de introduzir a pesquisa os movimentos para estabelecimento do campo de estudo; indicaçâo de lacuna a preencher no campo; informaçâo sobre a origem da pesquisa; apresentaçâo/discussâo dos resultados preliminares do momento inicial da pesquisa; identificaçâo de tema e objeto de pesquisa; apresentaçâo do objeto de estudo; da questâo de pesquisa; dos seus objetivos; realizaçâo da sua justificativa; seu delineamento teórico; apresentaçâo da estrutura organizacional da monografia.

Por um lado, estes movimentos se assemelham aos que Bhatia (2004) e Bezerra (2006) identificaram em introduçôes acadêmicas. Por outro, săo açôes específicas nos nossos dados, como o fato de as monografias recolhidas retomarem as pesquisas do PIBIC no movimento de informar sobre a origem da pesquisa. Além disso, săo características essenciais em introduçōes de monografias a apresentaçăo de questōes, objetivos e objeto de pesquisa, bem como a sua justificaçăo.

\section{CONSIDERAÇÕES FINAIS}

A falta de métodos científicos eficientes e a pouca habilidade no desenvolvimento de pesquisa dificultam a produçâo do gênero monografia. Entretanto, o sucesso de sua escrita exige tanta dedicaçấo quanto o progresso das investigaçóes que reverberam. 
Isso significa que as dificuldades na produçăo de monografias săo questôes que incluem a prática de escrita. Neste caso, vale a máxima de que se "aprende a escrever escrevendo". Assim, ainda que seja produzido apenas uma vez em um curso de graduaçăo, o entendimento e exercício desta (re)escrita em processo corrobora para atender às expectativas diante de sua complexidade de produzir e divulgar ciência.

Do contrário a essa visâo processual, repercutem ideias equivocadas de que este gênero deveria, inclusive, ser extinto das obrigatoriedades para se concluir uma graduaçấo, pelo teor de dificuldade de que sua produçáo nâo teria relaçâo com o desenvolvimento profissional de um licenciado/bacharel. O equívoco diverge da açâo social deste gênero de favorecer a um sujeito graduando a oportunidade de construir, apresentar e divulgar uma pesquisa com sua identidade profissional.

Em outros gêneros produzidos na academia, um estudante busca atender a solicitaçōes de professores, em tarefas estudantis, ou busca se inserir em comunidades acadêmicas, através de participaçăo/publicaçăo em eventos científicos e em revistas de (ou que aceitem) iniciaçăo científica. Muito embora, estudantes têm em monografias a autonomia de analisar um evento importante de ser pesquisado para sua formaçăo profissional, acadêmica e para a continuidade da ciência. Aliás, a análise empreendida pode dificultar a continuidade em níveis mais avançados do fazer científico, em pósgraduaçôes, quando sua insuficiência desqualifica seu sujeito produtor, que tende a empreender maior esforço para se inserir em práticas de pesquisa que deveriam ter sido iniciadas na graduaçáo. Contudo, a proficiência nesta escrita empodera seu sujeito a desenvolver ciência com um perfil de pesquisador, que sabe romper paradigmas e defender outros encontrados.

As especificidades da escrita situada, neste trabalho, discutem o gênero monografia como uma açăo social e textual. Em específico, ao observarmos que, em cursos de graduaçáo, o referido gênero mobiliza o processo de ensino/aprendizagem de graduandos. Por outro lado, a descriçáo de monografias, através de Swales (1990; 2004) e Bhatia (2004; 2009), como uma açâo sociorretórica, possibilita aos membros de comunidades acadêmicas a validaçáo de seu curso de graduaçâo e a permissăo institucional para realizar trabalhos de pesquisa em pós-graduaçōes.

Em linhas conclusivas, reiteramos que năo basta ensinar a um graduando que uma monografia com boa estrutura tem começo, meio e fim, mas que sua produçáo escrita se torna adequada com o conteúdo produzido. Também, é insuficiente apresentar dicas para se fazer uma boa monografia, porque elas năo garantem a apropriaçăo escrita do gênero. Tanto uma quanto outra situação, na verdade, satirizam como é angustiante o processo de escrever monografias; porém, é um gênero indispensável para iniciar um sujeito nas práticas de pesquisa científica. 


\section{REFERÊNCIAS}

ANDRADE, Joăo Paulo dos Santos de. Retextualizaçăo no gênero prova, 2014. 100f. Dissertaçăo (Mestrado em Linguagem e Ensino). Universidade Federal de Campina Grande, Campina Grande - PB.

ARAÚJO, Antonia Dilamar, 1996. Lexical signalling: a study of unspecific-nouns in book reviews. Tese (Doutorado em Linguística) - Universidade Federal de Santa Catarina, Florianópolis, 1996.

ASKEHAVE, Inger; SWALES, John M. Genre identification and communicative purpose: a problem and a possible solution. Applied Linguistics, v. 22, n. 2, pp. 195-212, 2001.

ASSOCIAÇÂO BRASILEIRA DE NORMAS TÉCNICAS. Orientando sobre normas para trabalhos técnico-científicos. Sâo Leopoldo: ABNT, mar. 2008.

Informaçăo e documentaçăo - Trabalhos acadêmicos: NBR 14724:2011. 3. ed. Rio de Janeiro: ABNT, mar. 2011. Válida a partir de 17.4.2011.

BACHELLARD, G. A formaçăo do espírito científico. Rio de Janeiro: Contraponto, 1996.

BAZERMAN, Charles. Retórica da açăo letrada. Săo Paulo: Parábola, 2015.

BAWARSHI, Anis S.; REIFF, Mary Jo. [2010]. Gênero: história, teoria, pesquisa e ensino. Sâo Paulo: Parábola, 2013. Traduçăo de Benedito Gomes Bezerra.

BEZERRA, Benedito Gomes, 2001. A distribuiçăo das informaçóes em resenhas acadêmicas. Dissertaçâo (Mestrado em Linguística) - Universidade Federal do Ceará, Fortaleza.

2006. Gêneros introdutórios em livros acadêmicos. 243 f. Tese (Doutorado em Linguística) - Universidade Federal de Pernambuco, Recife.

BERKENKOTTER, C.; HUCKIN, T. N. Genre knowledge in disciplinary communication: cognition, culture, power. Hillsdale, NJ: LEA, 1995.

BHATIA, Vijay K. [1993]. Worlds of written discourse: a genre-based view. London: Continuum, 2004.

.A análise de gêneros hoje.[1997]. In:BEZERRA, Benedito Gomes; BIASI-RODRIGUES, Bernadete; CAVALCANTE, Mônica Magalhăes. (Orgs.). Gêneros e sequências textuais. Recife: EDUPE, 2009. pp. 159-195.

BIASI-RODRIGUES, Bernadete, 1998. Estratégias de conduçāo de informaçōes em resumos de dissertaçôes. Tese (Doutorado em Linguística) - Universidade Federal de Santa Catarina, 1998.

; ARAÚJO, Júlio César; SOUSA, Socorro Cláudia Tavares. Gêneros textuais e comunidades discursivas: um diálogo com John Swales. Belo Horizonte: Autêntica, 2009.

; BEZERRA, Benedito Gomes. Propósito comunicativo em análise de gêneros. In: Linguagem em (Dis)curso, Tubarăo, SC, v. 12, n. 1, pp. 231-249, jan./abr. 2012.

CAVALCANTI, M. Applied Linguistics: Brazilian perspectives. AILA Review. Amsterdam. v. 17. pp. 23-30, 2004. 
CAVALCANTI, M.; MOITA LOPES, L. P. Implementaçâo de pesquisa na sala de aula de línguas no contexto brasileiro. Trabalhos em Linguística Aplicada. Campinas, n. 17. pp. 133-144, 1991.

CELLARD, André. A análise documental. In: POUPART, Jean. (Org.) A pesquisa qualitativa: enfoques epistemológicos e metodológicos. Petrópolis: Vozes, 2008. pp. 295-317.

COULMAS, Florian. Escrita e sociedade. Săo Paulo: Parábola, 2014.

DASCAL, Marcelo. (Org.). Fundamentos metodológicos da linguística. Sáo Paulo: Global, 1978. DEMO, P. Pesquisa: princípio científico e educativo. Săo Paulo: Cortez, 2005.

FERREIRA, Elisa Cristina Amorim, 2014. Desenvolvimento da escrita na academia: investigaçáo longitudinal do percurso de licenciandos em letras. 198f. Dissertaçâo (Mestrado em Linguagem e Ensino). Universidade Federal de Campina Grande, Campina Grande - PB.

Aprender a escrever no ensino superior: o desafio de alunos de Letras. Campina Grande - PB: EDUFCG, 2015.

KLEIMAN, A. B.; CAVALCANTI, M. (Org.).Linguística Aplicada suas faces e interfaces. Campinas: Mercado de Letras, 2007.

KUHN, T. A estrutura das revoluçóes científicas. 4. ed. Săo Paulo: Perspectiva. 1996.

LAKATOS, E. M.; MARCONI, M. de A. Metodologia do trabalho científico: procedimentos básicos, pesquisa bibliográfica, projeto e relatório, publicaçōes e trabalhos científicos. 6 ed. Săo Paulo: Atlas, 2001.

MACHADO, Anna Rachel (coord.). Planejar gêneros acadêmicos. Săo Paulo: Parábola Editorial, 2004. v. 3. (Coleçâo Leitura e produçâo de textos técnicos e acadêmicos).

Resenha. Sâo Paulo: Parábola Editorial, 2004. vol. 2. (Coleçăo Leitura e produçâo de textos técnicos e acadêmicos).

Resumo. Săo Paulo: Parábola Editorial, 2004. vol. 1. (Coleçăo Leitura e produçăo de textos técnicos e acadêmicos).

Trabalhos de pesquisa: diários de leitura para revisâo bibliográfica. Sâo Paulo: Parábola Editorial, 2004. v. 4. (Coleçăo Leitura e produçăo de textos técnicos e acadêmicos).

MARCUSCHI, L. Antônio. [2001]. Da fala para a escrita: atividades de retextualizaçăo. 10. ed. Săo Paulo: Cortez, 2010.

MATENCIO, Maria de Lourdes Meirelles. Atividades de (re)textualizaçăo em práticas acadêmicas : um estudo do resumo. Scripta, v. 6, n. 11, p. 109-122. Belo Horizonte: PUC Minas. 2002.

Referenciaçáo e retextualizaçăo de textos acadêmicos: um estudo do resumo e da resenha. ANAIS DO III CONGRESSO INTERNACIONAL DA ABRALIN, março de 2003. pp. 1-11.

O recurso ao discurso do outro na formaçăo inicial: um estudo de textos de alunos de Letras. Intercâmbio (CD-ROM), Sâo Paulo, v. 14, pp. 1-14, 2004.

MOITA LOPES, L. P. (Org.). Oficina de Linguística Aplicada: a natureza social e educacional dos processos de ensino/ aprendizagem de línguas. Campinas: Mercado de Letras, 1996. 
Por uma Linguística Aplicada indisciplinar. Săo Paulo: Parábola, 2006.

MORAIS, Francineide Ferreira de, 2006. Apropriaçăo da escrita acadêmica por professor em formaçáo e implicaçóes na sua prática pedagógica. Dissertaçăo (Mestrado em Linguagem e Ensino). Universidade Federal de Campina Grande, Campina Grande - PB, 2006.

MOTTA-ROTH, Désirée, 1995. Rhetorical features and disciplinary cultures: a genrebased study of academic book reviews in linguistics, chemistry and economics. Tese (Doutorado em Linguística) - Universidade Federal de Santa Catarina, Florianópolis, 1995.

.Uma análise de gênero de resumos acadêmicos (abstracts) em economia, linguística e química. Revista do Centro de Artes e Letras, Santa Maria, UFSM, 18 (1-2), pp. 53-90, jan./ dez. 1996.

(Org.). Redaçăo acadêmica: princípios básicos. Santa Maria: Universidade Federal de Santa Maria, Imprensa Universitária, 2001.

: HENDGES, Graciela Rabuske. Produçâo textual na universidade. Săo Paulo: Parábola, 2010.

OLIVEIRA, Silvio Luiz de. Tratado de Metodologia Científica: projetos de pesquisas, TGI, TCC, Monografias, Dissertaçōes e Teses. 4. ed. Săo Paulo: Pioneira Thomson Learning, 2002 .

RAMOS, Wiliam César, 2004. Equacionamento das fases linguística e linguísticocomputacional de um programa computacional de auxílio à escrita de abstracts.187f. Dissertaçăo (Mestrado em Linguística e Língua Portuguesa) - Faculdade de Ciências e Letras, Universidade Estadual Paulista, Araraquara.

Um roteiro para a escrita de abstracts de artigos de pesquisa: estrutura retórica e técnicas de argumentaçăo. 345f. 2011. Tese (Doutorado em Linguística e Língua Portuguesa). Universidade Estadual Paulista, Faculdade de Ciências e Letras, Campus de Araraquara - SP. 2011.

RITTI-DIAS, Fernanda Goulart Ritti; BEZERRA, Benedito Gomes. Análise retórica de introduçôes de artigos científicos da área da saúde pública. Horizontes de Linguística Aplicada, Brasília, ano 12, n. 1, 2014, pp. 163-182.

SANTOS, Joelma da Silva, 2009. Impactos do estudo da escrita produzidos nos textos de graduandos em letras. 228f. Dissertaçăo (Mestrado em Linguagem e Ensino). Universidade Federal de Campina Grande, Campina Grande - PB.

SANTOS, M. B. The textual organization of research paper abstracts in applied linguistiCs. Text, 16(4), pp. 481-499, 1996.

SILVA, Elizabeth Maria da (Org.). Professora, como é que se faz?. Campina Grande: Bagagem, 2012.

Academic abstracts: a genre analysis, 1995. Dissertaçăo (Mestrado em Inglês). Universidade Federal de Santa Catarina, Florianópolis.

SOUZA, Clara Regina Rodrigues de, 2014. Retextualizaçăo no gênero monografia. 148f. Dissertaçăo (Mestrado em Linguagem e Ensino) - Universidade Federal de Campina Grande, Campina Grande - PB. 
STRAUSS, Anselm; CORBIN, Juliet. Pesquisa qualitativa: procedimentos para o desenvolvimento de teoria fundamentada. 2. ed. Porto Alegre: Artmed, 2008.

SWALES, John M. Genre analysis: English in academic and researching settings. Cambridge: Cambridge University Press, 1990.

Research genres: exploration and applications. Cambridge: Cambridge University Press, 2004.

Repensando gêneros: nova abordagem ao conceito de comunidade discursiva. In: BEZERRA, Benedito Gomes; BIASI-RODRIGUES, Bernadete; CAVALCANTE, Mônica Magalhăes. (Orgs.). Gêneros e sequências textuais. Traduçăo de Benedito Gomes Bezerra. Recife: EDUPE, 2009, pp. 197-220.

. Texts and Commentaries: Toward a Reception Study of "Genre in Three Traditions" (Hyon, 1996). Conferência realizada em: Genre 2012: Rethinking Genre 20 Years Later, an international conference on genre studies. Carleton University Ottawa: Canada, 26 de jun. de 2012. Disponível em: http://www3.carleton.ca/genre2012. Acesso em: 15 out 2013.

APÊNDICE: Referências bibliográficas dos dados coletados

\begin{tabular}{|c|c|}
\hline \multicolumn{2}{|r|}{ Monografias de Ciências Sociais } \\
\hline MCS-1 & $\begin{array}{l}\text { NUNES, A. M. B. (Re)pecuarização e mudança social da agricultura familiar no sertāo do Pajeú } \\
\text { (PE): reconversões produtivas, reelaborações discursivas e mudança figuracional no Sítio Santo Izidro } \\
\text { (PE). } 61 \text { p. Monografia. (Curso de Ciências Sociais/ Bacharelado em Ciências Sociais) [2011]. }\end{array}$ \\
\hline MCS-2 & $\begin{array}{c}\text { MENESES, V. F. A constituiçâo de mediadores sociais em projetos de desenvolvimento: uma } \\
\text { reflexão sobre os ADRS no contexto da (re)pecuarização no cariri paraibano. } 69 \text { p. Monografia. (Curso } \\
\text { de Ciências Sociais/ Bacharelado em Ciências Sociais) [2011]. }\end{array}$ \\
\hline MCS-3 & $\begin{array}{l}\text { CAMILO, A. S. "Andarilhos no meio do mundo": os diferentes caminhos trilhados pelos ciganos e } \\
\text { o desafio de estar em Patos - PB. } 112 \text { p. Monografia. (Curso de Ciências Sociais/ Bacharelado em } \\
\text { Ciências Sociais) [2011]. }\end{array}$ \\
\hline \multicolumn{2}{|r|}{ Monografias de Letras } \\
\hline ML-1 & $\begin{array}{l}\text { MEIRA, G. H. S. A prática de seminários e as unidades retóricas como fatores intervenientes. } 75 \text { p. } \\
\text { Monografia. (Curso de Letras/ Habilitação em Língua Portuguesa) [2011]. }\end{array}$ \\
\hline ML-2 & $\begin{array}{c}\text { LIRA, D. M. Práticas de ensino e de avaliaçâo e concepçôes de escrita em curso de formaçâo } \\
\text { inicial de professor de língua materna. } 43 \text { p. Monografia. (Curso de Letras/ Habilitação em Língua } \\
\text { Portuguesa) [2010]. }\end{array}$ \\
\hline ML-3 & $\begin{array}{l}\text { SILVA, P. S. L. Saberes sobre oralidade mobilizados na formaçâo e na atuação de professores de } \\
\text { língua portuguesa. } 67 \text { p. Monografia. (Curso de Letras/ Habilitação em Língua Portuguesa) [2009]. }\end{array}$ \\
\hline
\end{tabular}

